University of Wollongong

Research Online

Faculty of Law, Humanities and the Arts Papers (Archive)

Faculty of Arts, Social Sciences \& Humanities

$1-1-2013$

The Philippine claim to Bajo de Masinloc in the context of the South China Sea dispute

Lowell Bautista

University of Wollongong, lowell@uow.edu.au

Follow this and additional works at: https://ro.uow.edu.au/lhapapers

Part of the Arts and Humanities Commons, and the Law Commons

Research Online is the open access institutional repository for the University of Wollongong. For further information contact the UOW Library: research-pubs@uow.edu.au 


\title{
The Philippine claim to Bajo de Masinloc in the context of the South China Sea dispute
}

\begin{abstract}
The Philippine claim to Bajo de Masinloc, otherwise referred to as Scarborough Shoal, finds solid basis in international law. The territorial claim of the Philippines over Bajo de Masinloc is strong relative to the claim of China as well as with respect to the principles on the acquisition of territory in international law, in particular, on the basis of effective occupation. The sovereign rights and jurisdiction asserted by the Philippines over the maritime entitlements of the features in Bajo de Masinloc are founded on principles of international law and consistent with the United Nations Convention on the Law of the Sea, which both the Philippines and China have signed and ratified. This paper aims to examine the Philippine claim over Bajo de Masinloc particularly focusing on the 2012 standoff between the Philippines and China and the arbitration case filed by the Philippines against China over the West Philippine Sea.
\end{abstract}

\section{Keywords}

de, bajo, claim, philippine, dispute, china, sea, south, context, masinloc

\section{Disciplines}

Arts and Humanities | Law

\section{Publication Details}

L. Bautista, 'The Philippine claim to Bajo de Masinloc in the context of the South China Sea dispute' (2013) 6 (2) Journal of East Asia and International Law 497-529. 


\title{
The Philippine Claim to Bajo de Masinloc/Scarborough Shoal in the Context of the South China Sea Dispute
}

\author{
Lowell B. Bautista*
}

The Philippine claim to Bajo de Masinloc, otherwise referred to as Scarborough Shoal, finds solid basis in international law. The territorial claim of the Philippines over Bajo de Masinloc is strong relative to the claim of China as well as with respect to the principles on the acquisition of territory in international law, in particular, on the basis of effective occupation. The sovereign rights and jurisdiction asserted by the Philippines over the maritime entitlements of the features in Bajo de Masinloc are founded on principles of international law and consistent with the United Nations Convention on the Law of the Sea, which both the Philippines and China have signed and ratified. This paper aims to examine the Philippine claim over Bajo de Masinloc particularly focusing on the 2012 standoff between the Philippines and China and the arbitration case filed by the Philippines against China over the West Philippine Sea.

Keywords: Philippine claim, Scarborough Shoal, Bajo de Masinloc, South China Sea

\section{Introduction}

The Philippine claim to Bajo de Masinloc, otherwise referred to as Scarborough Shoal, finds solid basis in international law. The territorial claim of the Philippines over Bajo de Masinloc is strong relative to the claim of China as well as with respect to the principles on the acquisition of territory in international law, in particular, on the basis of effective occupation. ${ }^{2}$ The sovereign rights and jurisdiction asserted by the Philippines over the

\footnotetext{
*Lecturer of law at the University of Wollongong. PhD (Wollongong); LL.M. (Dalhousie); LL.B/B.A., cum laude (Philippines). The author is grateful to Professors Jay Batongbacal, Aileen Baviera, and Diane Desierto for their helpful comments. The views expressed in this paper are those of the author and do not represent the official position of the Philippine Government. The author may be contacted at: lowellbautista@gmail.com/Address: School of Law, University of Wollongong, Wollongong, NSW 2522 Australia.

${ }^{1}$ This paper adopts the Philippine name of Scarborough Shoal, which is Bajo de Masinloc. This paper treats China and Taiwan as one claimant and assumes that their positions over the Bajo de Masinloc are identical.

${ }^{2}$ R. Jennings, The Acquisition of Territory in International LaW 6 (1963). See also S. SHARMA, TERritorial ACQUisition, DisPUtes, AND INTERNATIONAL LAW 188 (1997); H. KelsEN, PRINCIPLES OF INTERNATIONAL LAW 225 (2003); S. OdA, FifTY YEARS OF THE LAW OF THE SEA 22-27 (2003).
} 
maritime entitlements of the features in Bajo de Masinloc are founded on general principles of international law and consistent with the United Nations Convention on the Law of the Sea ("UNCLOS"), which both the Philippines and China have signed and ratified. ${ }^{3}$

The Philippines considers Bajo de Masinloc an integral part of Philippine territory on the basis of continuous, peaceful and exclusive exercise of effective occupation and effective jurisdiction over the shoal. ${ }^{4}$ The Philippine claim over Bajo de Masinloc is not based on proximity despite the same being located 120 nautical miles west of the nearest coast of the Philippine island of Luzon and more than 350 nautical miles from the nearest coast of China. ${ }^{5}$ The title of the Philippines is not based on the cession of the Philippine archipelago from Spain to the United States under the 1898 Treaty of Paris and related colonial treaties. ${ }^{6}$ In this regard, the non-inclusion of the features within the limits of the Treaty of Paris is immaterial and of no consequence.

The Philippine title over the insular features of Bajo de Masinloc is not founded on UNCLOS. UNCLOS does not address competing territorial claims, which is governed by general principles of international law relating to the acquisition of territory. However, the maritime entitlement of the features of the shoal as well as the nature and the corresponding rights and jurisdiction over the expanse of water around these

\footnotetext{
${ }^{3}$ United Nations Convention on the Law of the Sea, 10 December 1982, 1833 UNTS 3, [1994] ATS 31, 21 ILM 1261 (1982). [Hereinafter, UNCLOS]. The Philippines and China ratified UNCLOS on May 8, 1984 and June 7, 1996.

${ }^{4}$ Department of Foreign Affairs, Philippine position on Bajo de Masinloc (Scarborough Shoal) and the waters within its vicinity, Official Gazette of the Republic of the Philippines, Apr. 18, 2012.

${ }^{5}$ Republic of the Philippines, Department of Foreign Affairs, Notification and Statement of Claim, Manila I 10, (Jan. 22 2013).

${ }^{6}$ Three colonial treaties define the Philippine territorial boundaries: (1) Treaty of Paris, U.S.Spain, Dec. 10, 1898, T.S. No. 343; (2) Cession of Outlying Islands of Philippines, U.S.-Spain, Nov. 7, 1900, T.S. No. 345; (3) Boundaries, Philippines and North Borneo, U.S.-U.K., Jan. 2, 1930, T.S. No. 856. For materials that discuss the Philippine Treaty Limits, please see: L. Bautista, 'The Historical Context and Legal Basis of the Philippine Treaty Limits,' 10 AsIAN PACIFIC LAW AND Policy Journal 1 - 31 (2008); L. Bautista, Philippine Boundaries: Internal Tensions, Colonial Baggage, Ambivalent Conformity, 16 J. SOUTHEAST AsIAN STUD. 35-54 (2011); L. Bautista, The Legal Status of the Philippine Treaty Limits in International Law, 1 AEGEAN REV. L. SEA \& MARITIME L. 1ll-139 (2010); L. Bautista, The Historical Background, Geographical Extent and Legal Bases of the Philippine Territorial Water Claim, 8 J. COMP. AsIAN DEV. 365-395 (2009); L. Bautista, The Philippine Treaty Limits and Territorial Water Claim in International Law, 5 SOC. SCI. DiLIMAN 107 - 127 (2007).
} 
features are properly within the framework of UNCLOS. It is indisputable that Bajo de Masinloc is within the Exclusive Economic Zone ("EEZ") of the Philippines and the continental shelf of the Philippine archipelago, over which UNCLOS specifically grants the Philippines the exclusive sovereign rights to explore, exploit, conserve and manage living and non-living natural resources in the superjacent waters as well as in the continental shelf.' Bajo de Masinloc is not part of the Kalayaan Island Group ("KIG") or the Spratlys. ${ }^{8}$ The Philippine claim over Bajo de Masinloc is distinct from and independent of the Philippine claim over the KIG. ${ }^{9}$

The long-standing territorial and maritime jurisdictional disputes over the South China Sea have endured for decades. Despite the intermittent diplomatic disagreements and occasional threat of armed hostilities elsewhere in the South China Sea, especially over the Spratlys, Bajo de Masinloc have been relatively uneventful and peaceful. However, in recent times, Bajo de Masinloc has attained notoriety as tension in the region rose to alarming levels over a protracted stand-off between the Philippines and China in 2012 and continue to be contentious as a result of an international arbitration case under Annex VII of UNCLOS filed by the Philippines against China in 2013 over the West Philippine Sea and currently pending with the Permanent Court of Arbitration.

This research aims to examine the Philippine claim over Bajo de Masinloc. This paper will be of five parts including the Introduction and the Conclusion. Part two will provide an overview of the complex nature of the territorial and maritime dispute over Bajo de Masinloc within the context of the dispute over the South China Sea. It will discuss the geography and strategic importance and economic resource potential of Bajo de Masinloc contrasting the Philippine and Chinese claims over the South China Sea. Part three will discuss the Philippine claim over Bajo de Masinloc. This part will expound on the geographical extent, legal and historical bases of the Philippine claim

\footnotetext{
${ }^{7}$ UNCLOS art. 56 (1)(a) \& 77(1). It is also entitled to a 12 nautical mile territorial sea under UNCLOS art. 12l(3), where the Philippines exercises full sovereignty and jurisdiction as provided for in UNCLOS art. 2.

${ }^{8}$ Supra note 4.

9 J. ArReglado, KalayaAn: Historical, Legal and Political BaCKGround (1982); H. Yorac, The Philippine Claim to the Spratly Islands Group, 58 PHILIPPINE L. J. 172 (1983).
} 
and sovereign acts performed by the Philippine government over Bajo de Masinloc. It will also examine the Philippine claim under international law and consider its implications on maritime boundary delimitation. Part four will outline and discuss current developments in respect of Bajo de Masinloc, particularly focusing on the 2012 standoff between the Philippines and China and the arbitration case filed by the Philippines against China over the West Philippine Sea.

\section{Contest over Scarborough Shoal: With References to the Dispute in the South China Sea}

The contest over territorial sovereignty on Scarborough Shoal is part of, and inextricably linked to, the bigger dispute over the South China Sea. The issue of territorial sovereignty over the South China Sea is complex for the following reasons: first, because of the number of parties directly and indirectly involved; second, geo-political and strategic importance; and third, its economic resource potential. ${ }^{10}$

\section{A. Geographical Setting}

\section{The South China Sea}

The South China Sea is a semi-enclosed sea ${ }^{11}$ encompassing an area of around 3,500,000 $\mathrm{km}^{2}$ surrounded by the countries of Southeast Asia. The South China Sea encovers a portion of the Pacific Ocean stretching roughly from Singapore and the Strait of Malacca in the southwest, to the Strait of Taiwan in the northeast. The sea is bordered by Borneo to the south; China and Taiwan to the north; Vietnam, Thailand and Peninsular Malaysia to the west, and the Philippines to the east. It encompasses a continuation of the Pacific

\footnotetext{
${ }^{10}$ L. Bautista, Thinking Outside the Box: The South China Sea Issue and the United Nations Convention on the Law of the Sea (Options, Limitations and Prospects), 81 PHILIPPINE L. J. 699- 700 (2007).

${ }^{11}$ UNCLOS art. 122-123.
} 
Ocean stretching roughly from Singapore and the Straits of Malacca in the southwest, to the Straits of Taiwan (between Taiwan and China) in the northeast. ${ }^{12}$

In the South China Sea, there are over 250 islands, atolls, cays, shoals, reefs, and sandbars, most of which have no native inhabitants. These islands can be further subdivided into four sub-archipelagos, listed by area size: (1) the Spratly Islands; (2) the Macclesfield Islands; (3) the Paracel Islands; and (4) the Pratas Islands. The majority of the disputed islands are located in the Paracel and Spratly Island chains. ${ }^{13}$

\section{Bajo de Masinloc}

Scarborough Shoal is known by several names. It is referred to as Bajo de Masinloc or Panatag Shoal by the Philippines and Huangyan Island by China. Bajo de Masinloc, located approximately at latitude $15^{\circ} 08^{\prime} \mathrm{N}$ and longitude $117^{\circ} 45^{\prime} \mathrm{E}$, constitutes an atoll of reefs and rocks located about 124 nautical miles from the nearest coast of the Philippine island Luzon and approximately 472 nautical miles from the nearest coast of China. Bajo de Masinloc, the largest atoll in the South China Sea, is a ring-shaped coral reef formation, with several rocks encircling a lagoon. These rocks measure about 3 meters high above water with about five of which are above water at high tide while the rest are submerged during high tide. Bajo de Masinloc is situated north of the Spratlys, approximately along latitude $15^{\circ} 08^{\prime} \mathrm{N}$ and longitude $117^{\circ} 45^{\prime} \mathrm{E}$, between the Macclesfield Bank and Luzon Island of the Philippines in the South China Sea. ${ }^{14}$

\footnotetext{
${ }^{12}$ Z. Gao \& B. Jia, The Nine-Dash Line in the South China Sea: History, Status and Implications, AM. J. INT'L L. 99 (2013).

${ }^{13}$ Z. KeYUAN, LAW OF THE SEA IN EAST ASIA: IsSUES AND PROSPECTS 47 (2005).

${ }^{14}$ Supra note 4.
} 


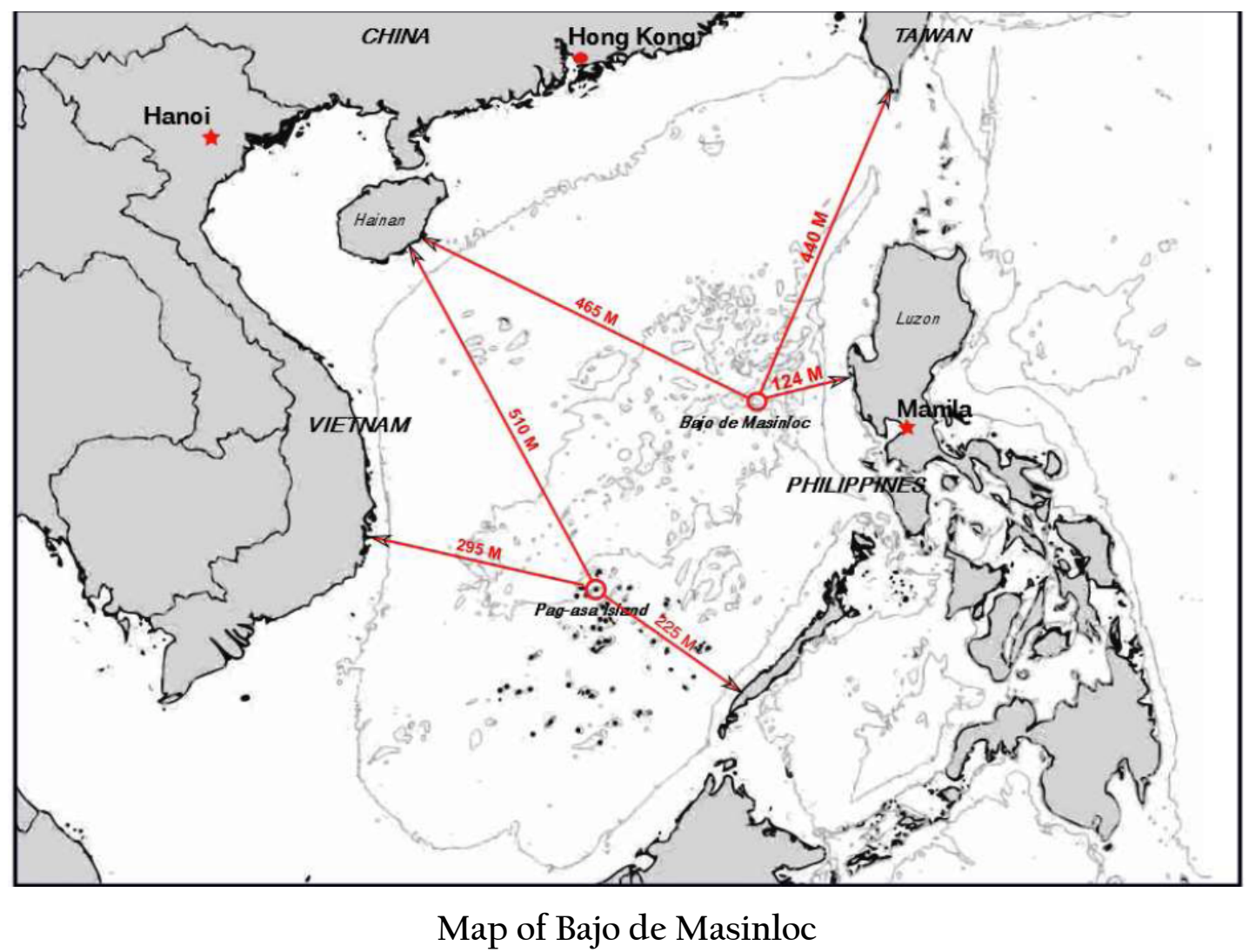

Source: A. Baviera \& J. Batongbacal, The West Philippine Sea: The Territorial and Maritime Jurisdiction Disputes from a Filipino Perspective - A Primer, The Asian Center and Institute for Maritime Affairs and the Law of the Sea, University of the Philippines, at 5 (2013), available at http:/filomenitamongaya.com/wpcontent/uploads/2013/07/UP_Primer-on-the-West-Philippine-Sea_April-2013_0.pdf (last visited on Oct. 6, 2013).

\section{B. Strategic Importance and Economic Resource Potential}

\section{South China Sea}

The South China Sea is strategically located. It straddles the main sealanes between Asia, the Middle East, and Europe; thus, a major international artery for maritime trade and transportation ${ }^{15}$ where over half of the world's supertanker traffic passes. The geopolitical and economic importance of the South China Sea renders the secure

\footnotetext{
${ }^{15}$ C. Rahman \& M. Tsamenyi, A Strategic Perspective on Security and Naval Issues in the South China Sea, 41 OCEAN DEV, \& INT’L L. 316-321 (2010).
} 
navigation of vessels in its waters a global concern. The region likewise plays a strategic naval and military role in maintaining global maritime security. ${ }^{16}$

The South China Sea, aside from its hydrocarbon potential in terms of oil and natural gas, is also a valuable marine resource. The Chinese estimates that potential hydrocarbon resources (not proved reserves) of the South China Sea at 17 billion tonnes of oil and 498 trillion cubic feet of natural gas. ${ }^{17}$ This optimism, however, is not shared by non-Chinese analysts. ${ }^{18}$ In 2010, the United States Geological Survey ("USGS") estimated that undiscovered conventional oil reserves of the South China Sea range between approximately $1400 \mathrm{Mb}$ and $5000 \mathrm{Mb} .{ }^{19}$ This is in stark contrast to the 1993/94 USGS estimate of 28 billion barrels of discovered reserves and undiscovered resources in the offshore basins of the South China Sea. ${ }^{20}$ The United States Energy Information Administration estimates that the South China Sea contains approximately 11 billion barrels of oil and 190 trillion cubic feet of natural gas in proved and probable reserves. ${ }^{21}$

\section{Bajo de Masinloc}

The waters around Bajo de Masinloc are considered valuable for the fisheries resources associated with it. ${ }^{22}$ Philippine local fishermen from the provinces of Zambales, Bataan and Pangasinan consider Bajo de Masinloc an important source of livelihood, with an annual potential yield of 5,021 metric tons annually. ${ }^{23}$ It is also important for ecological

\footnotetext{
${ }^{16}$ C. Schofield, Dangerous ground: A Geopolitical Overview of the South China Sea, in SECURITY AND INTERNATIONAL POLITICS IN THE SOUTH CHINA SEA: TOWARDS A COOPERATIVE MANAGEMENT REGIME 18-19 (S. Bateman \& R. Emmers eds., 2009).

${ }^{17}$ S. RAINE \& C. Le Miere, Regional Disorder: THe SOUth China SEA DisPutes 74-75 (2013).

${ }^{18}$ N. Owen \& C. Schofield, Disputed South China Sea hydrocarbons in perspective, 36 MARINE POL'Y 09$822(2012)$.

${ }^{19}$ Id. 815.

${ }^{20} \mathrm{Id}$.

${ }^{21}$ South China Sea, United States Energy Information Administration Website, (Feb. 7, 2013), available at http://www.eia.gov/countries/analysisbriefs/South_China_Sea/south_china_sea.pdf (last visited on Sept. 1, 2013).

${ }^{22}$ F. Bonnet, Geopolitics of Scarborough Shoal, at 7, Irasec's Discussion Papers No.14 (2012).

${ }^{23}$ A. Baviera \& J. Batongbacal, The West Philippine Sea: The Territorial and Maritime Jurisdiction Disputes from a Filipino Perspective - A Primer, The Asian Center and Institute for Maritime Affairs and the Law of the Sea, University of the Philippines, at 28 (2013), available at
} 
reasons being a rich feeding and breeding ground for all kinds of fish and marine species. ${ }^{24}$ In terms of hydrocarbon and other mineral resources, available geologic data does not indicate the probability of finding these resources in the area. However, it is believed that the seamounts in the area may hold massive amounts of sulfides and cobaltrich crusts. ${ }^{25}$ Bajo de Masinloc being astride major shipping routes renders it important to the Philippines for strategic reasons on grounds of national security.

For China, the strategic importance of Bajo de Masinloc lies in its pivotal role as a fulcrum in its claim over the South China Sea. The Chinese claims the shoal as part of a larger archipelago called the Zhongsha Qundao which includies Macclesfield Bank, Truro Shoal, Dreyer Shoal, Saint Esprit Shoal and Scarborough Shoal. ${ }^{26}$ Zhongsha Qundao, located in the northern part of the South China Sea, is comprised almost entirely of submerged features, except for the few rocks of Bajo de Masinloc which remain above water at high tide. Thus, the decisive role of Bajo de Masinloc for the Chinese claim over Zhongsha Qundao and consequently on the features located inside the "nine-dashed line". The legal consequences of China losing sovereignty over Bajo de Masinloc would be fatal on its claim over Zhongsha Qundao, and consequently over its entire claim over the South China Sea on the basis of the nine-dashed line. ${ }^{27}$ Without the shoal, the waters of Zhongsha Qundao will be part of the EEZs of the littoral States or placed under the regime of the high seas. ${ }^{28}$ This is the reason why China insists that the rocks of Bajo de Masinloc are 'islands' under Article 121 of UNCLOS in order to justify its assertion to draw, not only a territorial sea, but also an EEZ and continental shelf around the features. ${ }^{29}$

http:/filomenitamongaya.com/wp-content/uploads/2013/07/UP_Primer-on-the-West-

Philippine-Sea_April-2013_0.pdf (last visited on Oct. 6, 2013).

${ }^{24} \mathrm{Id}$.

${ }^{25} \mathrm{Id}$.

${ }^{26}$ Supra note 22, at 5 .

${ }^{27}$ For Chinese position over the South China Sea dispute, see Junwu Pan, Territorial Dispute between China and Vietnam in the South China Sea: A Chinese Lawyer's Perspective, 5 J. EAST ASIA \& INT'L L. 215-221 (2012).

${ }^{28}$ Id. at 4.

${ }^{29}$ Id. at 6. 


\section{The Philippine and Chinese claims over the South China Sea}

\section{Overlapping Maritime Claims and Maritime Boundaries between the Philippine and China}

Despite the broadly positive trend in the Philippine-China diplomatic and economic relations overall, the two countries' incompatible territorial and maritime claims provide a notable source of friction and, at times, serious diplomatic conflict, between them. As noted above, both the Philippines and China are parties to UNCLOS. China claims a territorial sea of $12 \mathrm{~nm},{ }^{30}$ a contiguous zone out to $24 \mathrm{~nm},{ }^{31}$ and an EEZ extending to $200 \mathrm{~nm},{ }^{32}$ all measured from its territorial sea baselines. In this context it is worth noting that in 2009 the Philippine Congress passed Republic Act No. 9522, a new law amending its old baselines law and defining archipelagic baselines for the Philippines. ${ }^{33}$ These claims are consistent with the relevant provisions of UNCLOS. For its part, China has defined system of straight baselines which encompasses much of its mainland coastline and around the Paracel Islands group. Accordingly, China treats waters landward of its territorial sea baselines as its internal waters. ${ }^{34}$ China's straight baseline claims have aroused international criticism, in large part because of their application along coastlines arguably not deeply indented or fringed by islands, the use of long baseline segments, and the apparent use of inappropriate baseline points. ${ }^{35}$ Further, China submitted preliminary information indicating the outer limits of the continental shelf beyond $200 \mathrm{~nm}$ with respect to the East China Sea on May 11, 2009, but reserved the right to make further submission for "other sea areas," ${ }^{36}$ It is also worth noting that Taiwan, who

\footnotetext{
${ }^{30}$ Law on the Territorial Sea and the Contiguous Zone art. 3.

${ }^{31}$ Id. art. 4.

${ }^{32}$ Exclusive Economic Zone and Continental Shelf Act art. 2

${ }^{33}$ Republic Act No. 9522, An Act to Amend Certain Provisions of Republic Act No. 3046, as amended by Republic Act No. 5446, to define the Archipelagic Baseline of the Philippines and for other Purposes, Mar. 10, 2009.

${ }^{34}$ Supra note 31. See also, Declaration of the Government of the People's Republic of China on the Baselines of the Territorial Sea (1996).

${ }^{35}$ United States Department of State, "Straight Baseline Claim: China," Limits in the Seas, No. 117 (Washington, D.C.: Office of Ocean Affairs, Bureau of Oceans and International Environmental and Scientific Affairs, U.S. Department of State, Jul. 9, 1996), available at http://www.state.gov/documents/organization/57692.pdf.

36 Preliminary Information Indicative of the Outer Limits of the Continental Shelf Beyond 200 Nautical Miles of the People's Republic of China (translation), May 11, 2009, I 10, available at http://www.un.org/depts/los/clcs_new/submissions_files/preliminary/chn2009preliminaryinform
} 
is not a member party to UNCLOS, has likewise defined straight baselines around its shores $^{37}$ and claimed maritime zones, including a 12nm territorial sea, a 200nm EEZ, and continental shelf rights. ${ }^{38}$

The Philippines has also enacted domestic legislation that is consistent with UNCLOS and, as noted above, has revised the baselines from which such claims are made. The Philippines claims a territorial sea that is unique in international law. The breadth of the Philippine territorial sea is variable, defined by coordinates set forth in the Philippine 'Treaty Limits.' In Philippine law, all the waters beyond the outermost islands of the archipelago, but within Philippine Treaty Limits, comprise the territorial sea of the Philippines. ${ }^{39}$ The Philippines also claims a 200nm EEZ, ${ }^{40}$ and a continental shelf of up to the limits of exploitability. ${ }^{41}$ Further, the Philippines filed a partial submission on the limits of its continental shelf beyond $200 \mathrm{~nm}$ in respect of the Benham Rise region located to the East of Luzon on April 8, 2009. The Philippines specifically reserved its rights to make submissions in respect of other areas, however.

The maritime claims of the Philippines and China overlap with one another and are complicated by the fact that the two States contest territorial sovereignty over several islands in the southern South China Sea and over Scarborough Shoal, located in the northeastern part of the South China Sea. Overall, four parts or sections to the overall China-Philippine maritime boundary delimitation can be distinguished as follows: First, a potential maritime boundary exists due north of the Philippines between the Philippine archipelago and Taiwan. Second, to the northwest of the Philippines a

ation_english.pdf (last visited on Sept. 30, 2013). For the international criticism, see Hyunsoo Kim, China's Basepoints and Baselines under the United Nations Convention on the Law of the Sea: A Critical Analysis, 6 J. EAST AsIA \& INT'L L. 135-153 (2013).

${ }^{37}$ This system of straight baselines is extensive and applies not only to Taiwan's main islands but Pratas Island and the Macclesfied Bank also. A comprehensive and critical analysis of this claim is provided by the US Deparment of State. See US Department of State, Taiwan's Maritime Claims, Limits in the Seas No. 127 (2005).

${ }^{38}$ For a detailed treatment of Taiwan's maritime claims, see K. Wang, The ROC's Maritime Claims and Practices with Special Reference to the South China Sea, 4l OCEAN DEV. \& INT'L L. 237- 252 (2010).

${ }^{39}$ L. Bautista, The Legal Status of the Philippine Treaty Limits in International Law," 1 AEGEAN REV. L. SEA \& MARITIME L. 111 - 139 (2010).

${ }^{40}$ Presidential Decree No. 1599, Jun. 11, 1978.

${ }^{41}$ Presidential Proclamation No. 370, Mar. 20, 1968. 
potential maritime boundary exists involving mainland China and Pratas Reef on the Chinese side. Third, and further to the south, China and the Philippines have a maritime boundary to delimit in the vicinity of Scarborough Shoal. Finally, the two States may have maritime boundaries to define with respect to the disputed Spratly Islands in the southern South China Sea. ${ }^{42}$

Proceeding further to the south and west, a theoretical line equidistant between China and the Philippines relies on basepoints located on the Pratas Islands (Dongsha Islands) on one side and the western coast of the major Philippine island of Luzon on the other. The Pratas Islands are located between the Chinese mainland coast and the Philippines and are currently governed by Taiwan, but also claimed by China. The Pratas Islands comprises three islands made up of coral atolls and reef flats in the northeastern side of the South China Sea, $850 \mathrm{~km}$ southwest of Taipei and $340 \mathrm{~km}$ southeast of Hong Kong. The main island, Pratas, is above sea level and is $2.8 \mathrm{~km}$ long and $0.865 \mathrm{~km}$ wide. Given the small size and thus restricted coastal front of the Pratas Islands in comparison to Luzon, if maritime boundary delimitation negotiations were ever initiated the Philippines would in all likelihood argue that Pratas Islands be accorded a reduced effect. It is also important to note that the equidistance line between these features and the Philippines cuts deep into the Philippine Treaty Limits.

\section{The Basis of the Chinese Claim over the South China Sea}

China claims territorial sovereignty over the entire South China Sea. It primarily anchors its claim on principle of 'discovery' on the basis of purported historical records that date as far back as the 200 B.C. ${ }^{43}$ China also relies on an 1887 treaty between France and China, which at that point delimited the territories of China and Vietnam, which was

\footnotetext{
${ }^{42}$ The Philippines and Taiwan also share overlapping EEZ claims to the north of the Philippines and south of Taiwan, having both proclaimed EEZs which extend 200nm from the baselines. See V. Prescott \& C. Schofield, The Maritime Political Boundaries of the World 434 (2005).

${ }^{43}$ J. Shen, China's Sovereignty over the South China Sea Islands: A Historical Perspective" I CHINESE J. INT'L L. 94 (2002).
} 
then a French protectorate ${ }^{44}$ China maintains troops on at least seven of the islands since 1988, including: (1) Da Chu Thap (Fiery Cross Reef); (2) Da Chau Vien (Cuarteron Reef); (3) Da Gac Ma (Johnson Reef); (4) Da Hu-go (Hughes Reef); (5) Da Gaven (Gaven Reef); (6) Da Su-bi (Subi Reef); and (7) Mischief Reef. ${ }^{45}$ China has erected structures on some of them, including a naval airfield on Fiery Cross Reef.

Taiwan's claim to the South China Sea is based on the principles of discovery and occupation. ${ }^{46}$ In 1946, Taiwan was the first to establish its presence in the Spratlys following the Japanese withdrawal after World War II. It has physically occupied and exercised sovereignty over Itu Aba (which it calls Taiping Island), the largest island in the Spratlys chain, since 1956.

China claims "indisputable sovereignty over the South China Sea islands and adjacent waters." This claim is often associated with a controversial map with nine (originally eleven) dashes. ${ }^{47}$ This map is often referred to as the "nine-dashed line" or, if the dashes are joined up, the "U-shaped line" ${ }^{48}$ which encloses the main island features of the South

${ }^{44}$ H. Chiu \& C. Park, Legal Status of the Paracel and Spratly Islands, 3 OCEAN DEV. \& INT'L L. I (1975); B. Murphy, Dangerous Ground: The Spratly Islands and International Law (1995) l OCEAN \& COASTAL L. J. $187 \& 191$ (1995).

${ }^{45}$ It must be clarified that the Philippines consistently maintains it has sovereignty over Mischief Reef, see D. Zha and M. Valencia, Mischief Reef: Geopolitics and implications, 31 J. ConTEMP. SOUTHEAST ASIA 86-103 (2001).

${ }^{46}$ China incorporates the claim of Taiwan into its own because China does not recognize Taiwan as an independent state separate from the PRC. See M. Bennett, The People's Republic of China and the Use of International Law in the Spratly Islands Dispute, 28 STAN. J. INT'L L.425 \& 448 (1992).

${ }^{47}$ For details, see Z. Gao \& B. Jia, The Nine-Dash Line in the South China Sea: History, Status and Implications, AM. J. INT'L L. 98-163 (2013); M. Gau, The U-Shaped Line and a Categorization of the Ocean Disputes in the South China Sea, 43 OCEAn DEV. \& INT'L L. 57-69 (2012); Z. Keyuan, China's U-Shaped Line in the South China Sea Revisited, 43 OCEAN DEV. \& INT'L L. 18-34 (2012); M. Miyoshi, China's "UShaped Line" Claim in the South China Sea: Any Validity Under International Law?, 43 OCEAN DEV. \& INT'L L 1-17 (2012); N. Thang \& N. Thao, China's Nine Dotted Lines in the South China Sea: The 2011 Exchange of Diplomatic Notes Between the Philippines and China, 43 OCEAN DEV. \& INT'L L. 35-56 (2012).

${ }^{48}$ Official Chinese sources have always depicted the line as a discontinuous. See for example, CLCS, Communication by China, (May 9, 2009), available at http://www.un.org/depts/los/clcs new/submissions files/mysvnm33 09/chn 2009re mys vnm e. pdf. (last visited 30 October 2013). 
China Sea. ${ }^{49}$ However, Beijing has never defined the precise locations of the dashes or provided their exact coordinates. It likewise remains unclear whether the dashed lines pertain merely to the enclosed island features, over the entirety of the waters they enclose, or to both. It is uncertain whether the nine-dashed line represents a maritime boundary, or a delineation of China's ownership over the islands, or a depiction of its historic title over the South China Sea. ${ }^{50}$

On May 7, 2009, China attached a map through a note submitted to the UN Commission on the Limits of the Continental Shelf ("CLCS"), which depicted the nine-dashed line." As the first officially publicized nine dashed-line map, it is arguably a recent articulation of China's official position on its maritime claims in the South China Sea. China used the note verbale and attached map to challenge the joint submission made by Malaysia and Vietnam on May 6, 2009 over their extended continental shelves in the South China Sea. ${ }^{52}$ Vietnam and Malaysia lodged diplomatic counter-protests in response to China's protest in May 8 and 20, 2009, respectively. ${ }^{53}$ On August 4, 2009, the Philippines also filed a diplomatic protest over the submissions made by Vietnam and Malaysia. On April 5, 2011, the Philippines also filed a diplomatic protest in response to China's May 7, 2009 diplomatic protest.

\footnotetext{
${ }^{49}$ L. Jinming \& L. Dexia, The Dotted Line on the Chinese Map of the South China Sea: A Note, 34 OCEAN DEV. \& INT'L L. 287-295 (2003). It is worth noting that the map was originally issued by the Republic of China (Taiwan) and included 11 rather than nine dashes.

${ }^{50} \mathrm{H}$. Thao, Vietnam's Position on the Sovereignty over the Paracels and the Spratlys: Its Maritime Claims, 5 JEAIL 204-207 (2012).

${ }_{51}$ CLCS, China Communication (May 7, 2009) available at http://www.un.org/depts/los/clcs new/submissions files/mysvnm33 09/chn 2009re mys vnm e. pdf (last visited 30 October 2013).

${ }^{52}$ CLCS, Joint Submission by Malaysia and Vietnam (May 6, 2009) available at http://www.un.org/depts/los/clcs new/submissions files/submission mysvnm 33 2009.htm (last visited 30 October 2013).

${ }^{53}$ CLCS, Vietnam Communication (May 8, 2009) available at http://www.un.org/depts/los/clcs new/submissions files/mysvnm33 09/vnm chn 2009re mys v nm e.pdf (last visited 30 October 2013); CLCS, Malaysia Communication (May 20, 2013) available at http://www.un.org/depts/los/clcs new/submissions files/mysvnm33 09/mys re chn 2009re mys vnm e.pdf (last visited 30 October 2013).
} 


\section{The Basis of the Philippine Claim over the South China Sea}

The Philippines essentially bases its claim to the South China Sea on the principle of discovery and effective occupation. ${ }^{54}$ The Philippines asserts that the Spratly Islands were terra nullius when Tomas Cloma, a Filipino lawyer and businessman, discovered them in 1947. On June 11, 1978, President Marcos issued Presidential Decree 1596, which placed the cluster of islands enclosed by defined coordinates starting from the Philippine Treaty Limits, "including the sea-bed, sub-soil, continental margin and air space" as "subject to the sovereignty of the Philippines." The decree stated that: "These areas do not legally belong to any state or nation but, by reason of history, indispensable need, and effective occupation and control established in accordance with the international law, such areas must now deemed to belong and subject to the sovereignty of the Philippines." ${ }^{55}$ The area was constituted as a municipality of the province of Palawan and collectively referred to as the "Kalayaan Island Group" (KIG). The Philippines occupies eight islands, including: Pag-asa (Thitu Island); Rizal Reef (Commodore Reef); Patag (Flat Island); Dagahoy Dugao/Kota (Loaita Island); Panata (Lankiam Cay); Lawak (Nanshan Island); Likas (West York Island); and Parola (North East Cay). Presidential Decree 1599, also enacted on June 11, 1978, which proclaimed a 200-mile exclusive economic zone for the Philippines, also include the KIG. ${ }^{56}$

\section{The Philippine Claim}

\section{A. Statement of the Philippine claim}

\footnotetext{
${ }^{54}$ For details, see H. Yorac, The Philippine Claim to the Spratly Islands Group, 58 PHILIPPINE L. J. 172 (1983); R. SeVerino, Where in the World is the PhilipPines: Debating its NATiOnAL TERRITORY 69-74 (2011).

${ }^{55}$ Presidential Decree No. 1596 (June 11, 1978) available at http://www.lawphil.net/statutes/presdecs/pdl978/pd 1596 1978.html. (last visited 30 October 2013).

${ }^{56}$ Presidential Decree No. 1599 (June 11, 1978) available at http://www.lawphil.net/statutes/presdecs/pd1978/pd 1599 1978.html (last visited 30 October 2013).
} 
The Philippines considers Bajo de Masinloc an integral part of Philippine territory. In the domestic local government structure, Bajo de Masinloc is part of the Municipality of Masinloc, Province of Zambales, located in Luzon, the biggest island of the Philippine archipelago. It is located 124 nautical miles west of Zambales and is within the Philippines' $200 \mathrm{~nm}$ EEZ and Philippine Continental Shelf. ${ }^{57}$

The Philippines makes a distinction between the basis of its "sovereignty and jurisdiction over the rock features of Bajo de Masinloc" from "its sovereign rights over the larger body of water and continental shelf. ${ }^{58}$ The Philippine exercise of full sovereignty and jurisdiction extends over the rocks of Bajo de Masinloc, while maintaining sovereign rights over the waters and continental shelf where the said rock features of Bajo de Masinloc are situated. ${ }^{59}$

The Philippine government asserts that its sovereignty and jurisdiction over Bajo de Masinloc are based on both the exercise of effective occupation and effective jurisdiction over Bajo de Masinloc since her independence. ${ }^{60}$ The Philippines clarifies that its claim over Bajo de Masinloc is "not premised on the cession by Spain of the Philippine archipelago to the United States under the Treaty of Paris"; as such, "[t]he matter that the rock features of Bajo de Masinloc are not included or within the limits of the Treaty of Paris as alleged by China is therefore immaterial and of no consequence." It is also "not premised on proximity or the fact that the rocks are within its 200-NM EEZ or CS under the LOSC" over which the "Philippines necessarily exercises sovereign rights" but "is anchored on other principles of public international law", namely effective occupation and effective jurisdiction. ${ }^{61}$

On the other hand, "the waters and continental shelves outside of the 12-nm territorial waters of the rocks of Bajo de Masinloc appropriately belong to the 200-nm

\footnotetext{
${ }^{57}$ Supra note 5.

${ }^{58} \mathrm{Id}$.

${ }^{59} \mathrm{Id}$.

${ }^{60} \mathrm{Id}$.

${ }^{61} \mathrm{Id}$.
} 
EEZ and CS of the Philippine archipelago." ${ }^{62}$ In this respect, "the Philippines exercises exclusive sovereign rights to explore and exploit the resources within the said areas to the exclusion of other countries under UNCLOS", which specifically provides that the "Philippines exercise exclusive sovereign rights to explore, exploit, conserve, and manage resources, whether living or nonliving, in this area. ${ }^{63}$

The Philippine position is that "Bajo de Masinloc is not an island," "64 but rather "rocks both literally and under Article 121 of UNCLOS." 65 As such, the Philippines argues that "none of the rocks, which lie in close proximity to one another, generates entitlement to more than a $12 \mathrm{~nm}$ territorial sea. ${ }^{166}$ The Philippines considers Bajo de Masinloc as "submerged features that are below sea level at high tide, which qualifies as 'rocks' under Article 121(3) of the Convention, and generate an entitlement only to a Territorial Sea no broader than $12 \mathrm{~nm}{ }^{67}{ }^{67}$ The Philippines argues that: "Submerged features in the South China Sea that are not above sea level at high tide, and are not located in a coastal State's territorial sea, are part of the seabed and cannot be acquired by a State, or subjected to its sovereignty, unless they form part of that State's Continental Shelf under Part VI of the Convention." ${ }^{68}$

In relation to Bajo de Masinloc, the Philippines alleges as follows: First, "China has unlawfully prevented Philippine vessels from exploiting the living resources in-the waters adjacent to Scarborough Shoal." Second, "China has unlawfully claimed rights to, and has unlawfully exploited, the living and non-living resources in the Philippines' Exclusive Economic Zone and Continental Shelf, and has unlawfully prevented the Philippines from exploiting the living and non-living resources within its Exclusive

\footnotetext{
${ }^{62}$ Supra note 4.

${ }^{63}$ Supra note 5.

${ }^{64} \mathrm{Id}$.

${ }^{65}$ Supra note 6, I 20.

${ }^{66} \mathrm{Id}$.

${ }^{67}$ Id. $\Phi 31$.

${ }^{68}$ Id.
} 
Economic Zone and Continental Shelf"; and lastly, "China has unlawfully interfered with the exercise by the Philippines of its rights to navigation under the Convention." ${ }^{69}$

\section{Historical Basis}

The Philippine interest on the island and waters of the South China Sea can be traced to antiquity. Even during the early period of the history of the Filipino people, predating the four centuries of colonial rule under the Spaniards and the Americans, there were already documented linkages between early Filipinos and the rest of Southeast Asia and China. The proximity of Bajo de Masinloc to the western coast of Luzon, the largest island of the Philippine archipelago, almost certainly implies that there were inhabitants on the main archipelago who had prior knowledge and interest in those features. ${ }^{70}$

During the Spanish colonial period, Bajo de Masinloc has already been considered part of the Philippines. In fact, the name Bajo de Masinloc, literally meaning "Masinloc Shoal" or "Masinloc Reef", was the name given to the shoal by the Spanish who arrived in the archipelago in 1521 and colonized the country for over three centuries. However, the locals from nearby coastal towns of Southwest Luzon, who have long fished in the area, refer to it as "Karburo". Bajo de Masinloc has been depicted as part of the Philippines as reflected in several maps released during the Spanish colonial period, as early as $1734 .^{71}$ The Carta Hydrografica de las Islas Filipinas by Spanish cartographer Pedro Murillo Velarde, in 1774, depicted offshore features clearly labeled as "Panacot" or "Bajo de Masinloc" off the coast of Zambales. ${ }^{72}$ It was also depicted as Bajo de Masinloc in an 1899 "Mapa General, Islas Filipinas" published by Observatorio de Manila.

\footnotetext{
${ }^{69} \mathrm{Id}$.

${ }^{70}$ Supra note 25 , at 29.

${ }^{71}$ C. Santamaria, Ancient maps support PH claim over Scarborough, Rappler Website (Jun. 27, 2012), available at http:/www.rappler.com/nation/7655-ancient-maps-support-ph-claim-overscarborough (last visited on Sept. 15, 2013).

${ }^{72}$ Id.
} 


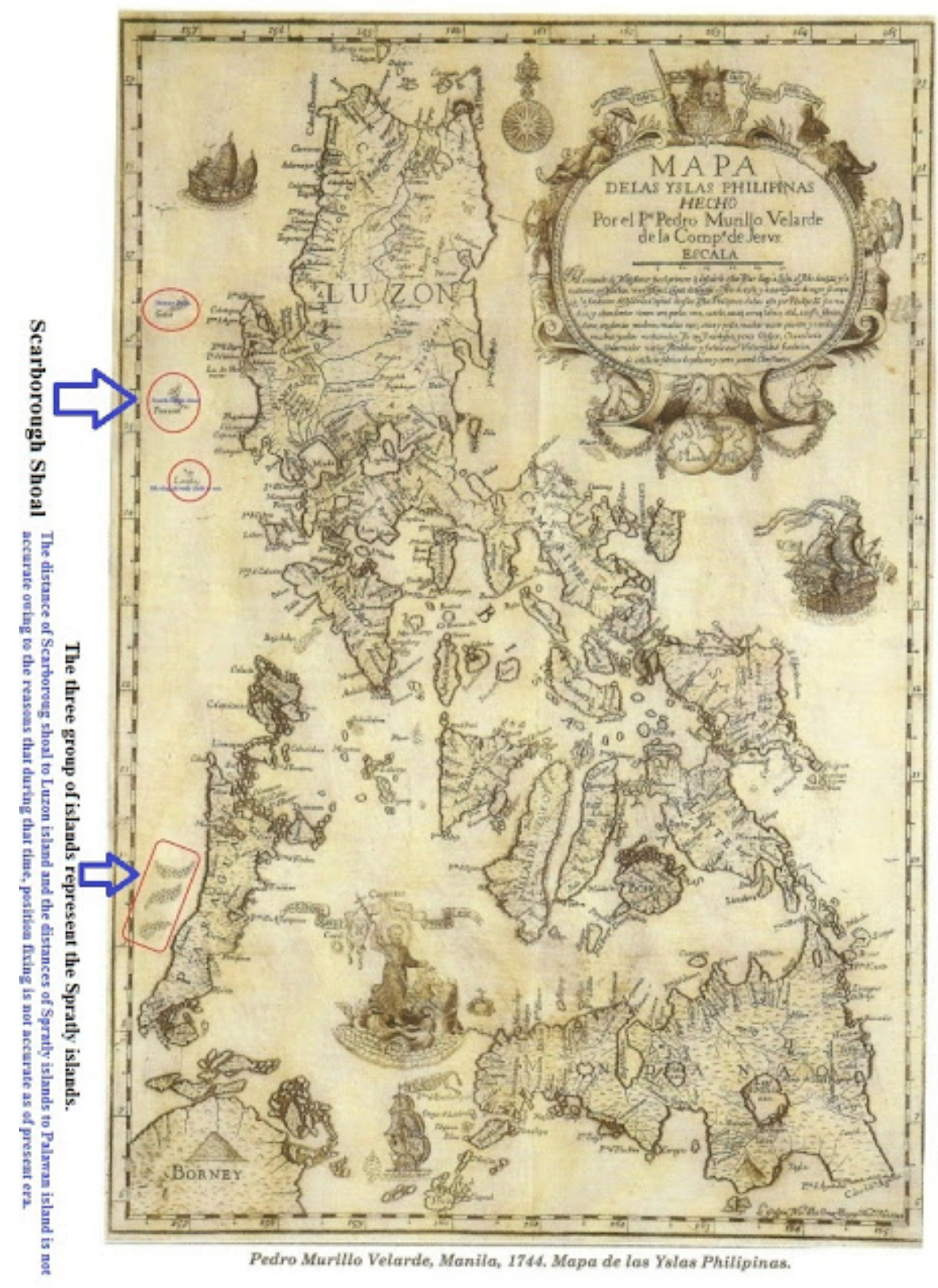

1744 Pedro Murillo Velarde Map showing Bajo de Masinloc

Source: http://jibraelangel2blog.blogspot.com.au/2012/07/three-hundred-years-of-philippine-maps.html 


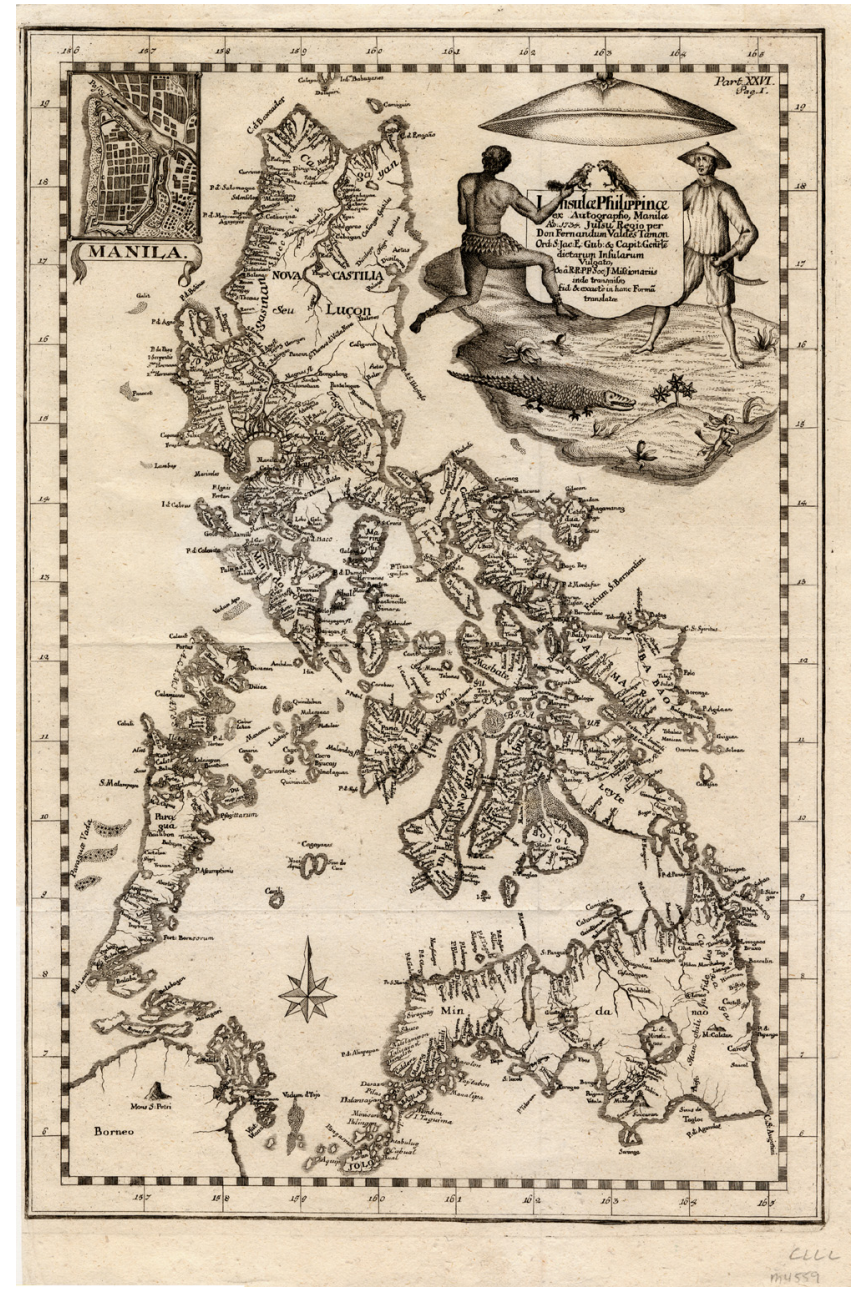

\section{4 map of the Philippine Islands depicting Scarborough Shoal as Panacot Shoal}

Source: http://en.wikipedia.org/wiki/File:1774 map of the Philippine Islands.jpg

The Shoal acquired its international name, 'Scarborough Shoal' after the shipwrecked British tea trading ship, 'SS Scarborough' in 1748, which is documented in British accounts. Another map from the 1789-1794 Alejandoro Malaspina Expedition drawn in 1792 and published in 1808 in Madrid Spain and reported in the 1939 Philippine Census Atlas also depicted Bajo de Masinloc as part of Philippine territory. ${ }^{73}$ The shoal has been a traditional fishing ground for Filipino fishermen for centuries. It was also noted in early $19^{\text {th }}$ century records as a source of pearls of excellent quality. ${ }^{74}$

\footnotetext{
${ }^{73}$ Supra note 23, at 4; Supra note 4.

${ }^{74}$ Supra note 22.
} 


\section{Geographical scope}

The Philippines does not claim the entirety of the South China Sea, which broadly refers to the semi-enclosed sea bordered by China, the Philippines, Malaysia, Indonesia, and Vietnam. It does claim the Kalayaan Island Group ("KIG"), otherwise referred to as the Spratly Islands, which lies in a shallow section of the South China Sea west of the Philippine archipelago. The area covered under the Philippine claim over KIG has clearly defined coordinates. ${ }^{75}$ It has also been reflected in official maps issued by the Philippines government and its agencies and instrumentalities. ${ }^{76}$ The claim explicitly mentions as belonging to and subject to the sovereignty of the Philippines the sea-bed, sub-soil, continental margin and air space covered in the said area. ${ }^{77}$ Bajo de Masinloc is not part of the KIG or the Spratlys. ${ }^{78}$

The term "West Philippine Sea" ("WPS"), on the other hand, refers to the part of the South China Sea that is the subject of Philippine sovereignty and/or jurisdictional claims. WPS includes "the Luzon Sea, as well as the waters around, within and adjacent to the KIG, and Bajo de Masinloc also known as Scarborough Shoal," ${ }^{79}$ the 200-nm Philippine EEZ and CS, measured from the archipelagic baselines defined in Republic Act 9522 (Philippine Baselines Law). ${ }^{80}$

\section{Sovereign Acts of the Philippine Government}

The sovereign acts of the Philippine Government over Bajo de Masinloc show that the Philippines has exercised jurisdiction over the insular features, especially in respect of maritime navigation. ${ }^{81}$ The Philippines through its Coast Guard and other maritime enforcement agencies have exercised administrative jurisdiction over Bajo de Masinloc

\footnotetext{
${ }^{75}$ Presidential Decree 1596 sec. 1.

${ }^{76}$ H. Yorac, The Philippine Claim to the Spratly Islands Group, 58 PHILIPPINE L. J. 173 (1983).

${ }^{77}$ Supra note 66.

${ }^{78}$ Supra note 4.

${ }^{79}$ Administrative Order No. 29, Naming the West Philippine Sea of the Republic of the Philippines, and for other Purposes, Sept. 5, 2012, Section 1.

${ }^{80}$ Republic Act No. 9522, Section 2(b).

${ }^{81}$ Supra note 23, at 32.
} 
for many years, through the enforcement of fisheries laws as evidenced by records showing apprehension of poachers and prevention of intrusions and illegal fishing activities in the area as well as search and rescue operations to vessels that transit the area regardless of flag. ${ }^{82}$

The argument that the Philippine claim is fairly recent is unwarranted and not supported by existing factual evidence that clearly suggest the contrary. ${ }^{83}$ While the shoal was outside the 1898 Treaty of Paris limits, the 1900 Treaty of Washington includes "any islands belonging to the Philippine archipelago, lying outside the lines...as if they had been expressly included within those lines." ${ }^{84}$ The Philippine Commonwealth Government (1935-1941) claimed Scarborough Shoal and regarded the same as "included among the islands ceded to the United States by the American-Spanish Treaty of November 7, 1900.. ${ }^{85}$ The US State Department had plans to build a small lighthouse on the shoal and the use of the shoal as "an aid to air and ocean navigation."

Since the 1950s, the Philippines has used the shoal as an impact range for defense purposes and conducted oceanographic surveys of the area with the US Navy, then based in the U.S. Naval Base in Subic Bay, Zambales. The Philippines built and operated a lighthouse on Scarborough Shoal in $1965 .{ }^{87}$ In 1992 , the lighthouse was rehabilitated by the Philippine Navy and reported to the International Maritime Organisation for publication in the List of Lights. Unfortunately, the same lighthouse is no longer operational. ${ }^{88}$ In addition, the Philippine flag has been erected and raised on the insular features of the shoal included an 8.3 meter flagpole in 1965 and another Philippine flag raised by then Philippine Congressman Roque Ablan and Jose Yap in $1997 .{ }^{89}$

${ }^{82}$ Id. at $35-36$.

${ }^{83}$ Supra note 22, at 10-12.

${ }^{84} \mathrm{Id}$.

${ }^{85} \mathrm{Id}$.

${ }^{86} \mathrm{Id}$.

${ }^{87}$ Supra note 4.

${ }^{88} \mathrm{Id}$.

${ }^{89} \mathrm{Id}$. 
There are other evidence of peaceful exercise of Philippine jurisdiction over Bajo de Masinloc which have not been protested by any other country. These include hydrographic survey by the Philippine Coast Guard in 1961, and law enforcement operations against smugglers in $1963 .{ }^{90}$

The 2009 Philippine Archipelagic Baselines Law reiterated the Philippine sovereignty and jurisdiction over the shoal and provided that baselines over the shoal should be determined using the regime of islands provision of UNCLOS. ${ }^{91}$ In 2012, Administrative Order No. 29 was passed naming areas including "the Luzon Sea as well as the waters around, within and adjacent to the Kalayaan Island Group and Bajo De Masinloc, also known as Scarborough Shoal" as the "West Philippine Sea." ${ }^{92}$

\section{B. An Examination of the Philippine Claim under International law}

The dispute over Bajo de Masinloc is both a territorial sovereignty dispute involving the question of ownership over the insular features, and a maritime jurisdictional entitlement issue. In respect of the first, the Philippine claim rests on the exercise of effective control, occupation, and jurisdiction, which are recognized modes of acquiring territory in international law; on the second, the Philippines relies on UNCLOS and principles consistent with UNCLOS, which embodies relevant rules of international law governing maritime entitlement of coastal States over their waters. ${ }^{93}$ In both aspects, the Philippine claim finds solid basis in international law.

The exercise of sovereignty by the Philippines over Bajo de Masinloc a titre de souvereign, as discussed above, have been peaceful and uninterrupted and have not been challenged by other countries until the 1980s. ${ }^{94}$ In international law, the exercise of effective control is considered the indispensable and essential condition of a strong

\footnotetext{
${ }^{90}$ Supra note 23, at 33.

${ }^{91}$ Supra note 71.

${ }^{92}$ Administrative Order No. 29 (2012).

${ }^{93}$ Supra note 4.

${ }^{94}$ Supra note 23, at 33.
} 
territorial claim. ${ }^{95}$ Effective occupation does not necessarily have to amount to possession, ${ }^{96}$ but the exercise of jurisdiction and state function on a continuous and peaceful basis depending on the particular circumstances of the case. ${ }^{97}$ It is not the sheer number alone that is of paramount importance, but the exercise of "continuous and peaceful display" right up to the moment of the critical date. ${ }^{98}$

In respect of the waters outside and around Bajo de Masinloc, the Philippines asserts sovereignty and jurisdiction over the same as clearly provided under UNCLOS. ${ }^{99}$ The insular features above water at high tide are rocks which generate a maximum $12 \mathrm{~nm}$ territorial sea, over which the Philippines asserts sovereignty. ${ }^{100}$ The waters beyond the $12 \mathrm{~nm}$ territorial sea limit generated from the insular features of Bajo de Masinloc are areas which indisputably lie within the Philippine EEZ and CS. ${ }^{101}$ Under UNCLOS, the Philippines exercises exclusive sovereign rights to explore, exploit, conserve and manage the resources, whether living or non-living, in this area to the exclusion of other countries. ${ }^{102}$

In contrast, the Chinese claim over Bajo de Masinloc covered within its "ninedashed line" claim on the basis of 'historic rights' is problematic under international law. ${ }^{103}$ The "nine-dashed line" is geographically imprecise having no exact coordinates, and unstable having been previously composed of eleven segments in 1947, with two lines subsequently removed in 1950. The "nine-dashed line" is also legally abstruse as its

\footnotetext{
${ }^{95}$ B. Sumner, Territorial Disputes at the International Court of Justice, 53 DUKE L. J. 1787 (2004).

${ }^{96}$ M. SHAW, INTERNATIONAL LAW 511 (2008).

${ }^{97}$ See Island of Palmas case, 2 RIAA $829 \& 840$ (1928); Eastern Greenland case, PCIJ Series A/B, No. 53, 46 (1933); Clipperton Island case, 26 AJIL 390 (1932); Minquiers and Ecrehos case, ICJ Reports 47 (1953).

${ }^{98}$ D. Johnson, Acquisitive Prescription in International Law, 27 BRITISH. Y.B. INT'L L. 342 (1950)

${ }^{99}$ UNCLOS parts II, V \& VI.

${ }^{100}$ Supra note 4.

${ }^{101}$ Supra note 4.

${ }^{102}$ UNCLOS arts. $56 \& 77$; parts V \& VII.

${ }^{103}$ The issue of the validity of China's claim over the South China Sea deserves longer treatment beyond the scope of this paper, for recent academic literature critical of the Chinese position. See H. Thao, Vietnam's Position on the Sovereignty over the Paracels and the Spratlys: Its Maritime Claims, 5 JEAIL 205-207 (2012); A. Carpio, The Rule of Law in the West Philippine Sea Dispute, Institute for Maritime and Ocean Affairs Website (Aug. 29, 2013), available at http://www.imoa.ph/speechthe-rule-of-law-in-the-west-philippine-sea-dispute/ (last visited on Sept. 1, 2013).
} 
official interpretation has been unarticulated. It is unclear what precise rights China claims over the waters and features enclosed within the line. The "nine-dashed line" has received neither international recognition, nor the acquiescence of States. ${ }^{104}$ On the contrary, it has been widely and consistently opposed. ${ }^{105}$

The argument that the waters enclosed by the "nine-dashed line" are historic waters of China is unsupported under international law. It obviously violates the principle that "the land dominates the sea" ${ }^{106}$ The nine-dashed line appears to be arbitrarily drawn entirely on water without any reference to a land feature over which China enjoys indisputable sovereignty as a starting point and from which the maritime entitlement should properly extend as provided for in international law. ${ }^{107}$ In international law, the legal title possessed by the State over its land territory is the "legal source of the power which a State may exercise over territorial extensions seaward."108 As the ICJ stated in the 1951 Anglo-Norwegian Fisheries Case, "it is the land which

\footnotetext{
104 Z. KEYUAN, LAW OF THE SEA IN EAST ASIA: ISSUES AND PROSPECTS 173 (2005). It reads: "It may be difficult for China to assert that there is a general acquiescence on the part of third states to its historic rights in the South China Sea..."

${ }^{105}$ M. VAlenCia, J. VAn Dyke \& N. LudWig, Sharing the Resources of the South China Sea 24 (1997); E. Franckx \& M. Benatar, Dots And Lines In The South China Sea: Insights From The Law Of Map Evidence, 2 AsiAn J. INT'L L. 113-115 (2012); M. Malik, Historical Fiction: China's South China Sea Claims, MAy/June WORLd AFFairs 83-90 (2013); M. Malik, A legal assessment of China's historic claims in the South China Sea, 5 Australian J, Maritime \& OCEan AfF. 28-36 (2013); F. Dupuy \& P. Dupuy, A legal analysis of China's historic rights claim in the South China Sea, 107 AJIL 124-141 (2013).

${ }^{106}$ I. Brownlie, Principles of Public International LaW 158 (2008). The Philippines in its Note Verbale of April 5, 2011 to the CLCS invokes the principle that "the land dominates the sea" to strongly challenge the validity of the nine-dotted line. CLCS, The Philippines Note Verbale No. 000228 (Apr. 5, 2011), available at http://www.un.org/depts/los/clcs_new/submissions_files/mysvnm33_09/phl_re_chn_2011.pdf (last visited on Sept. 1, 2013).

${ }^{107}$ At the 17th ASEAN Regional Forum ("ARF") Meeting in Hanoi on July 23, 2010, US Secretary Hilary Clinton stated that: "Consistent with customary international law, legitimate claims to maritime space in the South China Sea should be derived solely from legitimate claims to land features."

${ }^{108}$ North Sea Continental Shelf (Federal Republic of Germany v. Netherlands, Judgement 1969 I.C.J. I 96 (Feb. 26).
} 
confers upon the coastal State a right to the waters off its coasts." ${ }^{" 109}$ This general rule has been consistently affirmed by a long line of cases. ${ }^{110}$

The Chinese claim is also inconsistent with UNCLOS. ${ }^{111}$ Historic title under the Convention applies only in the delimitation of the territorial sea between States with opposite or adjacent coasts. ${ }^{112}$ It also does not fall within the exceptional regime of 'historic bays' or 'historic waters' as contemplated under customary international law. ${ }^{113}$

\section{Implications on Maritime Boundary Delimitation}

Bajo de Masinloc is the primary obstacle in the delimitation of the equidistance line between China and the Philippines. The main problem is whether the features can be classified as islands capable of generating EEZ and continental shelf claims or as "rocks" incapable of advancing such extended maritime claims consistent with Article 121 of UNCLOS. The general rule is that islands are to be treated in the same manner as other land territory. ${ }^{114}$ However, Article 121(3) of UNCLOS provides that: "Rocks which

\footnotetext{
${ }^{109}$ Fisheries (United Kingdom v. Norway), Judgment 1951 I.C.J. sec. 133 (Dec. 18).

${ }^{110}$ This reiterates the statement of the arbitral tribunal in the 1909 Grisba $\square$ darna case that "the maritime territory is essentially an appurtenance of a land territory." Grisba $\square$ darna Maritime Frontier (Norway v. Sweden), Award of the Arbitration, RIAA XI, $155 \& 159$. Thus, as the court stated in the Continental Shelf (Tunisia v. Libya Arab Jamahiriya) case, "the coast of the territory of the State is the decisive factor for title to submarine areas adjacent to it." Continental Shelf (Tunisia v. Libya Arab Jamahiriya), Judgment 1982 I.C.J. 6l (Feb. 24). For other cases which affirm the principle that the land dominates the sea, see, e.g., North Sea Continental Shelf (Federal Republic of Germany v. Netherlands), Judgement 1969 I.C.J. I 96 (Feb. 26); Maritime Delimitation and Territorial Questions (Qatar v. Bahrain), Judgment 2001 I.C.J. II 185 (Mar. 16). For other cases that affirmed this principle, see B. KWIATKOWSKA, DECISIONS OF THE WORLD COURT RELEVANT TO THE UN CONVENTION ON THE LAW OF THE SEA: A REFERENCE GUIDE 2-3 (2002).

${ }^{111}$ The question of historic waters is governed by customary international law. The few UNCLOS provisions which deal with historic title and historic bays do not contemplate nor support the extent and nature of the Chinese claim over the South China Sea based on the nine-dashed line. See UNCLOS art. 10(6), art. $15 \&$ art. 298 (1).

112 UNCLOS art. 15.

${ }^{113}$ Juridical Regime of Historic Waters, including Historic Bays, Document A/CN.4/143, 2 Yearbook of the International Law Commission (1962); C. SYMMONS, HISTORIC WATERS IN THE LAW OF THE SEA: A MODERN RE-APPRAISAL 139-160 (2007); M. STROHL, THE INTERNATIONAL LAW OF BAYS (1963); M. Clark, Historic Bays and Waters: A Regime of RECEnt BEginnings AND Continued USAGE (1994); F. Goldie, Historic Bays in International Law - An Impressionistic Overview, ll SYR J. INT’L L AND COM 271 (1984).

${ }^{114}$ UNCLOS art. 121(2).
} 
cannot sustain human habitation or economic life of their own shall have no exclusive economic zone or continental shelf." It is highly likely that whichever State ultimately obtains sovereignty over the feature, will claim that Bajo de Masinloc is capable of generating an EEZ and continental shelf rights and will seek to use it as a basepoint for maritime boundary delimitation.

In contrast, whichever of the two claimants does not obtain sovereignty over the feature is liable to argue that it should be treated as a mere 'rock.' If it were to be accorded full weight in the generation of maritime claims, the maritime spaces associated with Bajo de Masinloc have been estimated at approximately 54,000 square nautical miles $\left(185,500 \mathrm{~km}^{2}\right) .{ }^{115}$ That said, even if regarded as not capable of generating extended maritime claims, it would seem highly unlikely that Bajo de Masinloc would be accorded full weight as a basepoint for the construction of a maritime boundary, regardless of ownership. In either case, Bajo de Masinloc would present an extremely limited coastal front as compared to the coasts of either mainland China or the Philippine major island of Luzon.

\section{Recent Developments}

\section{A. The 2012 Stand-off between the Philippines and China}

The April 2012 standoff between the Philippines and China at Bajo de Masinloc brought tensions in the South China Sea to their highest level since the 1994 Mischief Reef incident. ${ }^{116}$ The standoff started on April 8, 2012, after eight Chinese fishing vessels anchored inside the lagoon of the Shoal were spotted by a Philippine Navy surveillance plane and confirmed by the Philippine Navy warship BRP Gregorio Del Pilar on the same

\footnotetext{
${ }^{115}$ Supra note 42 , at 434.

${ }^{116}$ K. Dawnay, The Scarborough Shoal Standoff, Current Intelligence Website (May 17 2012), available at http://www.currentintelligence.net/analysis/2012/5/17/the-scarborough-shoal-standoff.html (last visited on Sept. 30, 2013).
} 
day. ${ }^{117}$ On April 10, 2012, following established rules of engagement, a boarding team aboard BRP Gregorio del Pilar was dispatched to inspect the Chinese fishing vessels, collect photos and their catch. On the part of the Philippine boarding team, the apprehension of the Chinese fishermen was regarded as a routine maritime law enforcement operation which has been customary in Bajo de Masinloc. The Philippine boarding team, after inspection of the fishing vessels, discovered large amounts of illegally collected corals, giant clams and live sharks inside the first vessel. The arrest of the Chinese fishermen was blocked by two Chinese maritime surveillance ships, China Marine Surveillance 75 (Zhongguo Haijian 75) and China Marine Surveillance 84 (Zhongguo Haijian 84). ${ }^{118}$

On April 11, 2012, in order to de-escalate the tension, the Philippines replaced its surface combatant vessel with two civilian ships from the Coast Guard and the Bureau of Fisheries. On its part, China deployed the Yuzheng 310, its largest and most advanced patrol vessel equipped with machine guns, light cannons and electronic sensors. ${ }^{119}$ During the height of the standoff, in May 2012, there were at least 80 Chinese fishing vessels in Bajo de Masinloc. In July 2012, weather conditions brought about by a typhoon compelled the Philippines to pull-out which effectively left the shoal under the de facto control of the Chinese. ${ }^{120}$ The retaliatory actions of China against the Philippines during the standoff included punitive economic measures such as the imposition of a travel ban on Chinese tourists travelling to the Philippines, severe restrictions on the importation of bananas from the Philippines and the announcement of a unilateral fishing ban in the

117 Scarborough Shoal standoff: A timeline, Inquirer Website (May 9, 2012), available at http://globalnation.inquirer.net/36003/scarborough-shoal-standoff-a-historicaltimeline (last visited on Sept. 30, 2013).

${ }^{118}$ T. Santos, PH, Chinese naval vessels in Scarborough Shoal standoff, Philippine Daily Inquirer (Apr. 1l, 2012) available at http://globalnation.inquirer.net/32341/ph-chinese-naval-vessels-in-scarboroughshoal-standoff (last visited on Sept. 19, 2013).

${ }^{119}$ R. de Castro, China's Realpolitik Approach in the South China Sea Dispute: The Case of the 2012 Scarborough Shoal Standoff, Managing Tensions in the South China Sea Conference, Center for Strategic and International Studies, at 5 (2013); Department of Foreign Affairs, Philippines asserts sovereignty over Panatag (Scarborough) Shoal, Official Gazette Website (2012), available at http://www.gov.ph/2012/04/11/philippines-asserts-sovereignty-over-panatag-scarborough-shoal/ (last visited Sept. 30, 2013).

${ }^{120}$ Supra note 22, at 5. 
South China Sea covering the shoal. ${ }^{121}$ There were also other widespread rhetoric and propaganda from the Chinese alluding to the possibility of armed conflict erupting with veiled threats of using force against the Philippines. ${ }^{122}$ In July 2012, for the first time in its 45-year history, the Association of Southeast Nations ("ASEAN"), failed to issue a joint communiqué following its annual foreign ministers meeting in Phnom Penh, Cambodia, over intense disagreement whether the communiqué should reflect the confrontation between the Philippines and China over Scarborough Shoal. ${ }^{123}$

In September 2013, the Philippines released aerial surveillance photographs which showed about 75 concrete blocks allegedly installed by China on Bajo de Masinloc, which China denies. The Philippines is apprehensive that these concrete blocks could be used as platforms or foundations of larger structures in the area. ${ }^{124}$ The Philippines have declared plans to consider removing the concrete blocks allegedly installed by China on Bajo de Masinloc as well as filing a diplomatic protest. ${ }^{125}$ If the allegations of the Philippines were true, this would be tantamount to an occupation and represents a flagrant violation of the 2002 Declaration on the Conduct of Parties in the South China Sea ("DOC"). ${ }^{126}$ A regional security scholar, Ian Storey, said: "If China starts building at Scarborough, then it is an occupation and, I believe, the most egregious violation yet of the 2002 Declaration." ${ }^{127}$ The DOC enjoins parties "to exercise self-

\footnotetext{
${ }^{121}$ C. Thayer, Standoff in the South China Sea: Scarborough Shoal standoff reveals blunt edge of China's peaceful rise, YaleGlobal Website (Jun. 12, 2012), available at http://yaleglobal.yale.edu/content/standoffsouth-china-sea (last visited on Sept. 18, 2013).

${ }^{122}$ de Castro, supra note 119, at 7; Supra note 22.

${ }^{123}$ E. Bower, China reveals its hand on ASEAN in Phnom Penh, East Asia Forum Website (Jul. 28, 2012), available at http:/www.eastasiaforum.org/2012/07/28/china-reveals-its-hand-on-asean-in-phnompenh/(last visited on Sept. 18, 2013).

${ }^{124}$ Agence France-Presse, Philippines says it finds more Chinese blocks on reef, InTERAKSYON, Sept. 4, 2013, available at http://www.interaksyon.com/article/70057/philippines-says-it-finds-morechinese-blocks-on-reef (last visited on Sept. 18, 2013).

${ }^{125}$ Id.; L. Dalangin-Fernandez, Philippines to file another diplomatic protest vs China over Scarborough structures, INTERAKSYON, Sept. 5, 2013, available at http://www.interaksyon.com/article/70097/philippines-to-file-another-diplomatic-protest-vschina-over-scarborough-structures (last visited on Sept. 28 , 2013).

${ }^{126} \mathrm{M}$. Mogato \& B. Blanchard, Manila accuses China of sea violation, Beijing says wants peace, REUTERS, (Sept. 3 2013), available at http://www.reuters.com/article/2013/09/03/us-china-seasidUSBRE98207G20130903 (last visited on Sept. 30, 2013).

${ }^{127} \mathrm{Id}$.
} 
restraint in the conduct of activities that would complicate or escalate disputes and affect peace and stability including, among others, refraining from action of inhabiting on the presently uninhabited islands, reefs, shoals, cays, and other features..." ${ }^{128}$

\section{B. Philippine Arbitration against China over the West Philippine Sea}

\section{Institution of Arbitral Proceedings}

On January 22, 2013, the Philippines instituted arbitral proceedings against China under Article 287 and Annex VII of UNCLOS in order "to clearly establish the sovereign rights and jurisdiction of the Philippines over its maritime entitlements in the West Philippine Sea." ${ }^{129}$ On February 19, 2013, China rejected and returned the Philippine Notification through a Note Verbale in which it described "the Position of China on the South China Sea issues." The Permanent Court of Arbitration ("PCA") based in The Hague, serves as the Registry for the arbitration. The Arbitral Tribunal, composed of five members, is chaired by Judge Thomas A. Mensah of Ghana, along with Judge Jean-Pierre Cot of France, Judge Stanislaw Pawlak of Poland, Professor Alfred Soons of the Netherlands, and Judge Rüdiger Wolfrum of Germany. ${ }^{130}$ On July 11, 2013, the Arbitral Tribunal held its first meeting at the Peace Palace in the Hague. On August 27, 2013, the Arbitral Tribunal issued its first Procedural Order, establishing the initial timetable for the arbitration and adopting its Rules of Procedure. The Tribunal gave the Philippines until March 30, 2014 to submit its Memorial fully addressing "all issues, including matters relating to the jurisdiction of the Arbitral Tribunal, the admissibility of the Philippines' claim, as well as the merits of the dispute." ${ }^{131}$ The Tribunal provided the Philippines and China the opportunity to comment on the draft Rules of Procedure before the Rules of Procedure and timetable were adopted. The Philippines submitted

\footnotetext{
${ }^{128}$ Declaration on the Conduct of Parties in the South China Sea $\mathbb{} 5$.

${ }^{129}$ Supra note 5.

${ }^{130}$ The Republic of the Philippines v. The People's Republic of China, Permanent Court of Arbitration, available at http://www.pca-cpa.org/showpage.asp?pag_id=1529 (last visited on Sept. 30, 2013).

${ }^{131}$ Permanent Court of Arbitration Press Release, Arbitration between the Republic of the Philippines and the People's Republic of China: Arbitral Tribunal Establishes Rules of Procedure and Initial Timetable, The Hague, Aug. 27, 2013.
} 
comments on the draft on July 31, 2013, while China addressed a Note Verbale to PCA on August 1, 2013 reiterating its position that "it does not accept the arbitration initiated by the Philippines" and stating that "it was not participating in the proceedings." ${ }^{132}$

\section{Factual background}

The Philippines asserts that China's claim to 'sovereignty' and 'sovereign rights' over the maritime area within its so-called "nine dash line" encompassing virtually the entire South China Sea has interfered with the rights of the Philippines under UNCLOS over its own EEZ and CS, in violation of the Convention. ${ }^{133}$ In addition, China has seized control and occupied several small, uninhabitable coral projections, submerged features and protruding rocks barely above water at high tide, as well as claimed maritime zones surrounding these features greater than $12 \mathrm{~nm} .{ }^{134}$ Among these features include Mischief Reef, McKennan Reef, Gaven Reef and Subi Reef, which are at best low tide elevations and part of the Philippine continental shelf or the international seabed. ${ }^{135}$ The Philippines alleges further that China has also seized the following features in the Spratly Islands: Johnson Reef, Cuarteron Reef and Fiery Cross Reef, which it considers as "submerged reefs with no more than a few rocks protruding above sea level at high tide." 136

In essence, the Philippines is arguing as follows. First, these submerged features in the South China Sea which are not above sea level at high tide, are 'not' islands under the Convention. Second, these submerged features are part of the seabed and subject to the regime of the continental shelf under Part VI of UNCLOS and cannot be acquired by a State or subject to its sovereignty since they are not located in a coastal State's territorial sea. Third, since these submerged features are neither above sea level at high tide, nor are they located on China's continental shelf, the occupation of China of these submerged features is unlawful under the Convention. Fourth, the features which remain

\footnotetext{
${ }^{132} \mathrm{Id}$.

${ }^{133}$ Supra note 5, I 2.

${ }^{134}$ Id. II $4 \& 14$.

${ }^{135}$ Id. II $14 \& 19$.

${ }^{136}$ Id. II $22 \& 23$.
} 
above water at high tide qualify as 'rocks' under Article 121(3) of UNCLOS which only generate an entitlement of a maximum 12-nm territorial sea and anything beyond this is unlawful under the Convention, as China has claimed over the features. Last, China's exploitation and prevention of the Philippines from exploiting the living and non-living resources in the Philippines' EEZ and CS, as well as the interference with the exercise by the Philippines of its navigational rights over these waters, are all unlawful under the Convention. ${ }^{137}$

In relation specifically to Bajo de Masinloc, the Philippines alleges that in 2012: "China seized six small rocks that protrude above sea level within the Philippines' exclusive economic zone; unlawfully claimed an exaggerated maritime zone around these features; and wrongfully prevented the Philippines from navigating, or enjoying access to the living resources within this zone, even though it forms part of the Philippines' EEZ." ${ }^{138}$ As stated above, the Philippines asserts that the insular features of Bajo de Masinloc are 'rocks' under Article 121(3) of UNCLOS; yet, "China unlawfully claims entitlements to maritime zones greater than $12 \mathrm{~nm}$ in the waters and seabed surrounding them, and wrongfully excludes the Philippines and other States from these areas."139 Thus, in Bajo de Masinloc, "the maritime zones claimed by China unlawfully encroach upon the Philippines' 200 EEZ and CS extending from Luzon and Palawan, and prevent the Philippines from enjoying its rights under the Convention within $200 \mathrm{~nm} .{ }^{140}$

\section{Jurisdiction of the Tribunal}

UNCLOS, in Part XV, establishes a system of compulsory binding dispute settlement ("CBDS") for any dispute relating to the interpretation or application of any provision of the Convention. Therefore, in principle, a dispute between two States parties on the interpretation or application of a provision in UNCLOS, allows one party to the dispute to unilaterally invoke the CBDS system in Section 2 of Part XV..$^{141}$

\footnotetext{
${ }^{137}$ Id. פ 31.

${ }^{138}$ Id. I 20.

${ }^{139}$ Id. I 24.

${ }^{140} \mathrm{Id}$.

${ }^{141}$ UNCLOS art. 286. UNCLOS includes consent in its text. This is clear from the provisions of 74, 83, 186-191, 226, 264-265, 279-299, 309, 318. Annexes V, VI, VII, VIII. Article 309, on
} 
Both the Philippines and China, being parties to UNCLOS, subject to specified exceptions provided in the Convention, are bound by the CBDS regime. ${ }^{142}$ The Philippines asserts that the claims in the arbitration have been the subject of good faith negotiations and numerous exchange of views thereby satisfying Articles 279 and 283 of UNCLOS, requiring States parties to settle disputes by peaceful means in accordance with the UN Charter and the requirement for parties to proceed expeditiously to an exchange of views regarding a settlement by negotiation or other peaceful means, respectively. ${ }^{143}$

The failure of the Philippines and China to settle their dispute by peaceful means of their own choice, allows recourse to any of the procedures in Part XV, including compulsory procedures entailing binding decisions in Section 2 of Part XV, ${ }^{144}$ by submission to a tribunal having jurisdiction by the request of any party. ${ }^{145} \mathrm{~A}$ State party is allowed the choice of compulsory procedure, ${ }^{146}$ with arbitration under Annex VII as the default procedure when the parties to a dispute have not accepted the same procedure. ${ }^{147}$ Thus, since both the Philippines and China have not made any declaration, the instant dispute may only be submitted to arbitration in accordance with Annex VII. ${ }^{148}$

reservations and exceptions, provides that "No reservations or exceptions may be made to this Convention unless expressly permitted by other articles of this Convention." For details, see N. KLein, Dispute SeTtlement in the UN CONVENTION ON THE LAW OF THE SEA (2005); A.O. ADEDE, THE SYSTEM FOR SETTLEMENT OF DISPUTES UNDER THE UNITED NATIONS CONVENTION ON THE LAW OF THE SEA: A DRAFTING HISTORY AND A COMMENTARY (1987).

${ }^{142}$ UNCLOS art. 310 allows States and entities to make declarations or statements regarding its application at the time of signing, ratifying or acceding to the Convention, which do not purport to exclude or modify the legal effect of the provisions of the Convention. Art. 287 provides that States and entities, when signing, ratifying or acceding to the Convention, or at any time thereafter, may make declarations specifying the forums for the settlement of disputes which they accept. In addition, art. 298 allows States and entities to declare that they exclude the application of the compulsory binding procedures for the settlement of disputes under the Convention in respect of certain specified categories kinds of disputes.

${ }^{143}$ Supra note 5, IIJ 8 \& 25-30; UNCLOS arts. $279 \&$ \& 283(1).

${ }^{144}$ UNCLOS art. 281(1).

${ }^{145} \mathrm{Id}$. art 286.

${ }^{146} \mathrm{Id}$. art 287(1).

${ }^{147}$ Id. art 287(5).

${ }^{148}$ Id. art 287(5). 
UNCLOS allows States parties to declare in respect of certain specified categories kinds of disputes are excluded from the application of the compulsory binding procedures for the settlement of disputes under the Convention. ${ }^{149}$ China submitted a Declaration on August 25, 2006 under Article 298 of UNCLOS, which provides that: "The Government of the People's Republic of China does not accept any of the procedures provided for in Section 2 of Part XV of the Convention with respect to all the categories of disputes referred to in paragraph 1 (a) (b) and (c) of Article 298 of the Convention.. ${ }^{150}$ The Philippines is aware of the Chinese Declaration and has avoided raising subjects or claims that China has, by virtue of that Declaration, excluded from arbitral jurisdiction. ${ }^{151}$ The Philippines does not seek in the arbitration, "a determination of which Party enjoys sovereignty over the islands claimed by both of them. Nor does it request delimitation of any maritime boundaries. ${ }^{1152}$ Specifically, the Philippine claims are excluded from the Chinese Declaration, "because they do not: concern the interpretation or application of Articles 15, 74 and 83 relating to sea boundary delimitations; involve historic bays or titles within the meaning of the relevant provisions of the Convention; concern military activities or law enforcement activities; or concern matters over which the Security Council is exercising functions assigned to it by the UN Charter." ${ }^{153}$

\section{Relief Sought}

The Philippine arbitration case against China over the West Philippine Sea asks the Tribunal three fundamental questions. First, whether "the Parties' respective rights and obligations in regard to the waters, seabed and maritime features of the of the South China Sea are governed by UNCLOS, and that China's claims based on its "nine-dash

\footnotetext{
${ }^{149}$ Id. sec. 3, Part XV.

${ }^{150}$ China, Declaration made after ratification (Aug. 25, 2006), Declarations and statements, United Nations Division for Ocean Affairs and the Law of the Sea, available at http://www.un.org/depts/los/convention agreements/convention declarations.htm (last visited on Sept. 30, 2013).

${ }^{151}$ Supra note 5, פ 8.

${ }^{152}$ Supra note 5 , פ 7.

${ }^{153}$ Supra note 5, 940.
} 
line" are inconsistent with the Convention and therefore invalid." Second, whether "under Article 121 of UNCLOS, certain of the maritime features claimed by both China and the Philippines are islands, low tide elevations or submerged banks, and whether they are capable of generating entitlement to maritime zones greater than $12 \mathrm{~nm}$." Third, whether the Philippines should be allowed "to exercise and enjoy the rights within and beyond its exclusive economic zone and continental shelf that are established in the Convention.." ${ }^{154}$ The Philippines requests the Arbitral Tribunal to issue an Award seeking thirteen specific reliefs (See Annex 1). ${ }^{155}$

\section{Conclusion}

The bilateral relationship between the Philippines and China is mutually important for both countries. The Philippine-China bilateral relations have indeed expanded, deepened and are showing every sign of continuing to do so. It is undeniable that China is strategically important in Philippine foreign and security policy for historical, cultural, geographic, economic, and political reasons. At a strategic level, the Philippines is keenly aware and recognizes, in common with other nations around the world, the increasing economic, political, and military capabilities of China. However, Philippine relations with China, while increasingly strong, especially in economic terms, can in political and diplomatic terms be characterized largely as cautious, at best, and even hostile, at times. ${ }^{156}$

An enduring source of tension between the Philippines and China are contested territories and un-delimited maritime boundaries and overlapping maritime claims. In particular, an influential and often corrosive factor in their bilateral relations is their dispute over the South China Sea. Both countries are parties to UNCLOS and both refer to international law to support and bolster their respective claims. The Philippines and

\footnotetext{
${ }^{154}$ Supra note 5, פ 6.

${ }^{155}$ Supra note 5, פ 41.

${ }^{156}$ L. Bautista and C. Schofield, Philippine-China Border Relations: Cautious Engagement Amidst Enduring

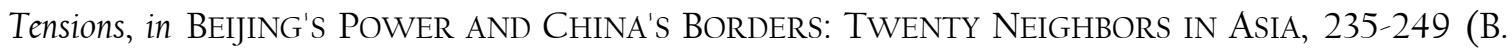
Elleman et al eds., 2012).
} 
China also both contest sovereignty over Bajo de Masinloc, located in the northeast of the South China Sea, which has been examined in this paper.

The territorial and maritime jurisdictional dispute over Bajo de Masinloc is inextricably linked to the dispute over the South China Sea. The issue of territorial sovereignty over Bajo de Masinloc remains a potential geopolitical flashpoint. While it is clear that the primary reason for the claims is based on its strategic location and its resource potential, this is more than a simple conflict over resources. The issue goes beyond the question of territorial sovereignty and natural resource jurisdiction. This is more than a legal question of ownership.

It is not realistic to foresee the prospects of a lasting and durable solution over the territorial and maritime disputes over the South China Sea in the near future. The escalation of tension and persistent threat of armed conflict are likely to remain and even intensify from time to time. The patriotic fervor that the dispute over the legal status of the islands of the South China Sea evokes among all the claimant countries renders their positions almost intractable and heightens the possibility of bloodshed and military conflict. The solution to this longstanding regional and global concern remains uncertain.

The Philippines, in respect of its claim over Bajo de Masinloc, much like China, echoes the same rhetoric: a solid basis in fact and in law for its claim. The legal framework under UNCLOS offers some options but the highly complicated nature of the dispute tests the limits of international law and obscures the possibility of a legal solution. ${ }^{157}$ More importantly, and perhaps often overlooked, the cultural aversion of Asians against a judicial settlement, where there are victors and losers, almost renders this option illusory. Whilst the dispute settlement mechanism within the framework of UNCLOS clearly creates an obligation among the claimant countries to settle their conflicting claims peacefully, it is only triggered as an option when parties are not able to

${ }^{157}$ N. Hong, UNClOS AND OCEAn Dispute Settlement: LAW and POlitics IN THE SOUTH ChInA SEA 54 (2012); Supra note 10; Y. Song \& S. Tønnesson, The Impact of the Law of the Sea Convention on Conflict and Conflict Management in the South China Sea, 44 ODIL 235-269 (2013). 
settle their differences by peaceful means of their choice. ${ }^{158}$ Ultimately, the primacy given over the sovereign equality of States under international law means that the effectiveness of this mechanism depends on the willingness of claimant States to formally invoke it.

The Philippines, from both a domestic and foreign policy perspective, needs to approach the issue over Bajo de Masinloc comprehensively and strategically. It must take into thoughtful consideration both short-term and long-term interests of the Philippines, balancing domestic imperatives that drive a more aggressive, and nationalistic position vis-à-vis China with the shifting and dynamic economic, military and power relations in the region and beyond. China, on its part, should not take advantage of its economic and military superiority to intimidate and threaten. China, on the cusp of being the next global superpower, is at the center of world attention and every indication that the coming Chinese century would not have a benevolent, international-law abiding, superpower does not augur well for China as well as the world.

Ultimately, it is to the mutual interest of both the Philippines and China to work towards the prevention of the escalation of conflicts, particularly military confrontations. Both the Philippines and China should continue to uphold and honor international law, exercise self-restraint and espouse the non-use of force in the articulation of their respective claims. The parties should continue to use diplomatic and other peaceful means to manage and resolve territorial disputes in the South China Sea through bilateral and multilateral initiatives, including actively pursuing the conclusion of a legally binding Code of Conduct on the South China Sea signed by all claimant States. The Philippine arbitration case should be regarded as a positive move in the right direction which allows a claimant State to pursue a rules-based approach based on international law, within the framework of UNCLOS, in resolving the dispute over Bajo de Masinloc.

${ }^{158}$ UNCLOS art. 286. 


\section{Annex 1}

1. Declares that China's rights in regard to maritime areas in the South China Sea, like the rights of the Philippines, are those that are established by UNCLOS, and consist of its rights to a Territorial Sea and Contiguous Zone under Part II of the Convention, to an EEZ under Part V, and to a Continental Shelf under Part VI;

2. Declares that China's maritime claims in the South China Sea based on its socalled "nine dash line" are contrary to UNCLOS and invalid;

3. Requires China to bring its domestic legislation into conformity with its obligations under UNCLOS;

4. Declares that Mischief Reef and McKennan Reef are submerged features that form part of the Continental Shelf of the Philippines under Part VI of the Convention, and that China's occupation of and construction activities on them violate the sovereign rights of the Philippines;

5. Requires that China end its occupation of and activities on Mischief Reef and McKenna Reef;

6. Declares that Gave Reef and Subi Reef are submerged features in the South China Sea that are not above sea level at high tide, are not islands under the Convention, and are not located on China's Continental Shelf, and that China's occupation of and construction activities on these features are unlawful;

7. Requires China to terminate its occupation of and activities on Gaven Reef and Subi Reef;

8. Declares that Scarborough Shoal, Johnson Reef, Cuarteron Reef ad Fiery Cross Reef are submerged features that are below sea level at high tide, except that each has small protrusions that remain above water at high tide, which are "rocks" under Article 12l(3) of the Convention and which therefore generate entitlements only to a Territorial Sea no broader than $12 \mathrm{M}$; and that China has unlawfully claimed entitlements beyond 12M from these features;

9. Requires that China refrain from preventing Philippine vessels from exploiting in a sustainable manner the living resources in the waters adjacent to Scarborough Shoal and Johnson Reef, and from undertaking other activities inconsistent with the Convention at or in the vicinity of these features; 
10. Declares that the Philippines is entitled under UNCLOS to a $12 \mathrm{M}$ Territorial Sea, a $200 \mathrm{M} \mathrm{EEZ,} \mathrm{and} \mathrm{a} \mathrm{Continental} \mathrm{Shelf} \mathrm{under} \mathrm{Parts} \mathrm{II,} \mathrm{V,} \mathrm{and} \mathrm{VI} \mathrm{of} \mathrm{UNCLOS,}$ measured from its archipelagic baselines;

11. Declares that China has unlawfully claimed and has unlawfully exploited the living and non-living and non-living resources in the Philippines' EEZ and Continental Shelf and has unlawfully prevented the Philippines from exploiting living and non-living resources within its EEZ and CS;

12. Declares that China has unlawfully interfered with the exercise by the Philippines of its rights to navigation and other rights under the Convention in areas within and beyond $200 \mathrm{M}$ of the Philippines' archipelagic baselines; and Requires that China desist from these unlawful activities 